\title{
Growth and dynamic modulus of elasticity of Pinus patula $\times$ Pinus tecunumanii hybrids in Mpumalanga, South Africa
}

\author{
Phillip C Hongwane ${ }^{1,2 *}$, R Glen Mitchell ${ }^{3}$, Arnulf Kanzler ${ }^{4}$, Steven D Verryn ${ }^{5}$ and Paxie WC Chirwa ${ }^{2}$ \\ ${ }^{1}$ Komatiland Forests Research, Sabie, South Africa \\ 2 Department of Plant and Soil Sciences, University of Pretoria, Pretoria, South Africa \\ ${ }^{3}$ Forest Solutions Malaysia, Kota Kinabalu, Malaysia \\ ${ }^{4}$ Sappi Forest Research, Howick, South Africa \\ ${ }^{5}$ Creation Breeding Innovations, Pretoria, South Africa \\ *Corresponding author, email: Phillip@safcol.co.za
}

\begin{abstract}
Field establishment of South Africa's most important commercial pine species, Pinus patula, is severely hampered by the pitch canker fungus, Fusarium circinatum. Importantly, hybrids between $P$. patula and other pine species tolerant to the pitch canker fungus, such as $P$. tecunumanii and $P$. oocarpa, have been identified as an alternative planting stock. In this study, variation in tree volume and dynamic modulus of elasticity $\left(\mathrm{MOE}_{\mathrm{dym}}\right)$ of the $P$. patula $\times P$. tecunumanii (low- and high-elevation [LE and HE] ecotypes) hybrid was compared with the $P$. elliottii $\times$ $P$. caribaea hybrid, and the pure species $P$. tecunumanii (LE) and $P$. patula. The $M_{0} E_{\text {dym }}$ was assessed using the Fakkop TreeSonic microsecond instrument across three sites. The results of the study showed that $P$. patula $\times$ $P$. tecunumanii LE performed significantly better than $P$. patula $\times P$. tecunumanii $\mathrm{HE}$ for volume and $\mathrm{MOE}_{\mathrm{dym}}$, which in turn was significantly better than $P$. patula. The $\mathrm{MOE}_{\mathrm{dym}}$ and tree growth decreased with an increase in elevation. There was significant taxon $\times$ site interaction for volume and $M_{0} E_{d y m}$. The results of these trials suggested that $P$. patula $\times P$. tecunumanii LE is a suitable alternative to $P$. patula in the Sabie region of Mpumalanga in South Africa on frost-free sites, in terms of the traits that were assessed.
\end{abstract}

Keywords: modulus of elasticity, pine hybrids, productivity, site index

Introduction

Pinus patula extends from $24^{\circ}$ to $17^{\circ} 30^{\prime} \mathrm{N}$ latitude in Mexico between altitudes of 1490 and 3100 m (Dvorak et al. 2000c). This species occurs in temperate climates where annual precipitation ranges between 1000 to 2500 $\mathrm{mm}$ and experiences up to five dry months in some places. The average temperature in this region ranges from 10 to $18^{\circ} \mathrm{C}$. In South Africa, P. patula is the most important pine species used to establish plantations due to its superior growth and wood properties (Dvorak et al. 2000c). This species is insensitive to changes in climatic conditions with regard to growth (Leibing et al. 2013). Pinus patula has proved to be an ideal timber for the production of saw logs, veneer logs and pulpwood. All commercial plantations of this species are managed to yield one or more of these products at the end of a rotation. The genetic improvement of $P$. patula started more than three decades ago with the main focus on growth rate, adaptability and stem characteristics. Pinus patula does very well on colder sites and above 1000 metres above sea level (masl) with an average annual rainfall of $800-900 \mathrm{~mm}$. It performs poorly on tropical sites.

Pinus tecunumanii occurs in Mexico, Guatemala, Honduras and Nicaragua between $12^{\circ} 42^{\prime} \mathrm{N}$ and $17^{\circ} 02^{\prime} \mathrm{N}$ in an altitudinal range of $450-2900 \mathrm{~m}$. It is found in areas where the annual precipitation is $1000-2500 \mathrm{~mm}$. The species is divided into two groups: low- and high-elevation populations (Dvorak et al. 2000b). On warmer sites it grows alongside other pine species, such as $P$. oocarpa and P. maximinoi.

In South Africa $P$. tecunumanii has shown outstanding growth, excellent wood properties and good tolerance to Fusarium circinatum (Dvorak et al. 2000b; Hodge and Dvorak 2000; Mitchell et al. 2012). Large variations between provenances and families of the high-elevation (HE) source of $P$. tecunumanii were reported (Hodge and Dvorak 2007; Mitchell et al. 2011). Pinus tecunumanii produces wood of similar or slightly higher density than $P$. patula, $P$. taeda and $P$. elliottii. In South Africa, Colombia and Brazil it was reported that $P$. tecunumanii was prone to stem breakage; however, this was noted to occur more frequently in the $\mathrm{HE}$ population (Hodge and Dvorak 1999; Leibing et al. 2013).

In the last few decades breeding to improve disease tolerance in pines has been a priority, particularly since the pitch canker fungus, $F$. circinatum, has become an established pathogen in South Africa (Viljoen et al. 1995). Post-planting survival of $P$. patula in South Africa has decreased as a result of this pathogen (Hodge and Dvorak 2007; Mitchell et al. 2012; Kanzler et al. 2014). The poor survival rates prompted the development of new hybrid combinations to overcome the mortality caused by 
F. circinatum. Mitchell et al. (2012) argued that planting $P$. elliottii and $P$. taeda to replace $P$. patula was not a suitable solution because these two species did not perform any better than $P$. patula in terms of volume yield on certain sites.

Fusarium circinatum screening trials indicated that $P$. elliottii $\times P$. caribaea and $P$. patula $\times P$. oocarpa hybrids are more tolerant than the maternal parent to the pitch canker fungus (Hodge and Dvorak 2007; Roux et al. 2007). This suggests that there is potential to select for disease tolerance given the large pool of different species and wide range of provenance material available in South Africa. This puts the industry in a position to develop, test and cross and then select the best hybrid combinations. Research and development of the $P$. patula $\times P$. tecunumanii hybrid has been ongoing for more than 20 years (Kanzler et al. 2014). Studies conducted in Swaziland and in the KwaZulu-Natal Midlands of South Africa demonstrated that $P$. patula $\times$ $P$. tecunumanii outperforms $P$. patula by an average of $23 \%$ in volume at the age of five years (Kanzler et al. 2012). The study also reported that $64 \%$ of the $P$. patula $\times$ $P$. tecunumanii families performed better than both $P$. patula and $P$. tecunumanii controls. Furthermore, the $P$. patula $\times$ $P$. tecunumanii hybrid was reported to be significantly more tolerant to $F$. circinatum than $P$. patula (Mitchell et al. 2012; Kanzler et al. 2014). Thus, due to these benefits, $P$. patula $\times P$. tecunumanii is now widely planted as an alternative to $P$. patula in South Africa.

In addition to increasing growth and disease tolerance of commercially grown forest trees, there is a need to improve wood quality and this has become an important component in breeding programmes around the world (Apiolaza et al. 2008). There are both destructive and non-destructive methods used to measure wood quality. Acoustic technology is a non-destructive technology used to measure the time-offlight of soundwaves through the wood of both standing trees and cut logs (Wielinga et al. 2009; Lowell et al. 2014). This technology has gained popularity as it is easy, quick and cheap to use, despite its limitations in that it measures the stiffness of the outer wood and is based on an assumption of constant wood density (Lowell et al. 2014). Strong correlations between modulus of elasticity (MOE), density and velocity have been reported (Johnson and Gartner 2006; Lindström et al. 2009). Johnson and Gartner (2006) reported a correlation of 0.91 for acoustic velocity and MOE of Pseudotsuga menziesii. Wang et al. (2007) reported a correlation of 0.89 for MOE and velocity, and 0.85 for MFA and velocity in $P$. radiata. The MOE is affected by wood density, microfibril angle (MFA) and moisture content (Johnson and Gartner 2006; Nilsson 2014).
The South African National Standard 1783 (SANS 1783-2 2012) makes provision for three structural grades for South African pine. Each grade has minimum requirements for MOE and density. Timber that is classified as S5 grade should have a minimum of $7.8 \mathrm{Gpa}$, S7 grade 9.6 Gpa and S10 grade $12 \mathrm{Gpa}$. In addition to MOE, each grade must have minimum densities of 360,425 and $475 \mathrm{~kg} \mathrm{~m}^{3}$, respectively (SABS 0163-2 2001).

The objectives of this study were to measure and compare the growth, and also the dynamic modulus of elasticity $\left(\mathrm{MOE}_{\mathrm{dym}}\right)$, of $P$. patula $\times P$. tecunumanii and some other crosses and pure species across a range of sites for the purpose of evaluating any benefits that the hybrid pine might have over more traditional species choices.

\section{Materials and methods}

\section{Study material}

Camcore (International Tree Breeding and Conservation Program) is an organisation based at North Carolina State University, USA. Camcore has members in the Americas, Africa and Australia; members collaborate and share genetic material in the form of pollen, seeds and vegetative cuttings for research and breeding purposes. A number of Camcore $P$. tecunumanii provenance/ family trials, testing unimproved material from Mexico and Central America, were planted in the early 1980s. Selections were made in these, some of which have been grafted into clone banks and seed orchards. Pollen harvested from these selections was used to produce the $P$. patula $\times P$. tecunumanii hybrids in the current trials. The first- and second-generation $P$. patula selections used in the crossing program had been developed within the Komatiland Forests breeding program. The hybrid seeds were used to establish seedling hedges at the Tweefontein nursery near Sabie (Mpumalanga, South Africa). Hedges were kept in groups according to pedigree (family). Cuttings were harvested from the hedges and pedigree information was maintained during the rooting process and trial establishment.

\section{Experimental design}

Six sites were selected for the trial series (Table 1). Entries were arranged in six-tree row plots within a randomised complete block design, replicated six times except for the trial established at Bergvliet where entries were arranged as single-tree plots (replicated 30 times). The trees were planted at an espacement of $3 \mathrm{~m} \times 3 \mathrm{~m}$. Pinus patula, $P$. taeda, P. elliottii, $P$. tecunumanii (LE source) seedlings

Table 1: General trial details for the six trial sites. MAT = mean annual temperature, MAP = mean annual precipitation

\begin{tabular}{|c|c|c|c|c|c|c|c|}
\hline Location & Planting date & $\begin{array}{l}\text { Plot size } \\
\text { (trees) }\end{array}$ & $\begin{array}{c}\text { Number of } \\
\text { replicates }\end{array}$ & $\begin{array}{l}\text { Altitude } \\
\text { (m) }\end{array}$ & $\begin{array}{l}\text { MAT } \\
\left({ }^{\circ} \mathrm{C}\right)\end{array}$ & $\begin{array}{l}\text { MAP } \\
(\mathrm{mm})\end{array}$ & $\begin{array}{c}\text { Soil clay } \\
(\%)\end{array}$ \\
\hline Spitskop1 & 10 December 2001 & $1 \times 6$ & 6 & 1310 & $16-18$ & $1050-1300$ & 35 \\
\hline Bergvliet & 11 December 2001 & $1 \times 1$ & 30 & 1051 & $14-16$ & $850-1050$ & 20 \\
\hline Jessievale & 13 November 2007 & $1 \times 6$ & 6 & 1723 & $14-16$ & $850-1050$ & 15 \\
\hline Spitskop2 & 13 February 2008 & $1 \times 6$ & 6 & 1460 & $16-18$ & $>1300$ & 35 \\
\hline Witklip & 10 March 2008 & $1 \times 6$ & 6 & 1058 & $14-16$ & $1050-1300$ & 25 \\
\hline Tweefontein & 13 March 2008 & $1 \times 6$ & 6 & 1250 & $16-18$ & $>1300$ & 40 \\
\hline
\end{tabular}


and $P$. elliotti $\times P$. caribaea var. hondurensis hybrid cuttings were included as controls in some of the trials (Table 2). Pinus greggii var. greggii (also known as the northern variety) was used in the $P$. patula $\times P$. greggii cross. The actual species/hybrid, number of families and total trees used for the analysis (values in parenthesis), for each trial are shown in Table 2. The seedling control entries were represented as a seed orchard mix of families. The $P$. patula controls represented a mix of first-generation $\left(F_{1}\right)$ and second-generation $\left(F_{2}\right)$ families as two separate entries. In the case of the $P$. patula $F_{2}$ entry, a mix of the best 10 families was used and at Bergvliet, Spitskop2 and Jessievale an additional best families were added separately as controls.

\section{Trial establishment}

For each trial, the plants were planted into pits that had been prepared on the same day of planting. Plants did not receive water at planting as the soils at all sites were considered sufficiently moist from earlier rainfall events.

\section{Data collection and analysis \\ Data collection}

The first survival assessment was carried out one month after planting. The dead plants were blanked soon after the survival assessment between 30 and $40 \mathrm{~d}$ after planting. In cases where there were an insufficient number of plants to blank, $P$. elliottii or $P$. taeda were used as fillers and recorded as such; fillers were excluded from assessment during measurements. The first growth assessment was carried out at three years of age followed by a five-year assessment. During the five-year assessment, wood quality was assessed by measuring acoustic velocity using the Fakopp TreeSonic microsecond instrument (Malan 2010) at three sites: Tweefontein, Witklip and Spitskop2. All trees in the trials were assessed and recorded.

The diameter at breast height $(\mathrm{DBH})$ and individual tree height $(H)$ were assessed for all trees. Tree volume was estimated using the volume equation for juvenile trees (Ladrach and Mazuera 1978):

$$
V=0.00003 \times \mathrm{H} \times \mathrm{DBH}^{2}
$$

where $V$ is the stem volume $\left(\mathrm{m}^{3}\right), \mathrm{DBH}$ is the over bark diameter at breast height $(\mathrm{cm})$ and $H$ is the tree height $(\mathrm{m})$.
Dynamic modulus of elasticity $\left(\mathrm{MOE}_{\mathrm{dym}}\right)$ was estimated by using the average time it takes for the stress wave to travel through the wood over $1 \mathrm{~m}$ using the Fakkop TreeSonic microsecond instrument and the following equation (Wielinga et al. 2009):

$$
\mathrm{MOE}_{\mathrm{dym}}=\rho V^{2} \times 10^{-3}
$$

where $\mathrm{MOE}_{\text {dym }}$ is the modulus of elasticity (Gpa), $V$ is the velocity of sound through the wood $\left(\mathrm{km} \mathrm{s}^{-1}\right)$ and $\rho$ is the wood density $\left(\mathrm{kg} \mathrm{m}^{-3}\right)$. The density is assumed to be constant at $1000 \mathrm{~kg} \mathrm{~m}^{-3}$ (Wielinga et al. 2009; Malan 2010).

\section{Data analysis}

All analyses and results presented in this work were based on the five-year data. Data were analysed using SAS 9.3 (SAS Institute, Cary, NC, USA, 2010). PROC GLM and the Student Newman-Keuls (SNK) test were used to distinguish entry differences at the $5 \%$ significance level. Individual tree volume and $\mathrm{MOE}_{\text {dym }}$ were corrected by subtracting the difference between the repetition mean and the trial mean. Corrected volume and $\mathrm{MOE}_{\text {dym }}$ were used to calculate the least squares means for volume and MOE $_{\text {dym. }}$ PROC GLM for individual sites was carried out to determine if there were significant differences between taxa (species/hybrid) for volume and $\mathrm{MOE}_{\text {dym }}$. All ANOVA results presented are type III sums of squares.

The models used for the analysis were:

$$
\bar{y}_{i j}=\mu+\operatorname{rep}_{i}+\operatorname{taxa}_{j}+\varepsilon_{i j}
$$

where $\bar{y}_{i j}$ is the $i$ th observed mean growth response of the $j$ th taxon, $\mu$ is the overall mean growth of taxa at possible environment, rep $_{i}$ represents the effect of the $i$ th rep, taxa is the effect of the $j$ th taxon, and $\varepsilon_{i j}$ is the random error term.

$$
\bar{y}_{j k}=\mu+\text { site }_{i}+\operatorname{rep}_{i j}+\operatorname{taxa}_{k}+\operatorname{taxa}_{k} * \operatorname{site}_{j}+\varepsilon_{i j k}
$$

where $\bar{y}_{k}$ is the $j$ th observed growth response of the $k$ th taxon, $\mu$ is the overall mean growth of taxa at possible environment, $\operatorname{rep}_{i j}$ represents the effect of the $i$ th rep in the $j$ th site, site ${ }_{j}$ is the fixed effect of the $j$ th site, $\operatorname{taxa}_{k}$ is the effect of the $k$ th taxon, taxa ${ }_{k}{ }^{*}$ site $_{j}$ is the interaction effect of the $k$ th taxon in the $i$ th site, and $\varepsilon_{i j k}$ is the random

\begin{tabular}{|c|c|c|c|c|c|c|}
\hline$\overline{\text { Taxon }^{1}}$ & Spitskop1 & Bergvliet & Jessievale & Spitskop2 & Witklip & Tweefontein \\
\hline P. elliottii & & & $\operatorname{Mix}(66)$ & & & \\
\hline P. ell×car & & & Mix (49) & $\operatorname{Mix}(28)$ & $\operatorname{Mix}(34)$ & Mix (34) \\
\hline P. patula $\left(\mathrm{F}_{1}\right)$ & $\operatorname{Mix}(11)$ & Mix (23) & & & & \\
\hline P. patula $\left(\mathrm{F}_{2}\right)$ & $\operatorname{Mix}(123)$ & $\operatorname{Mix}(121)$ & $\operatorname{Mix}(50)$ & $\operatorname{Mix}(27)$ & $\operatorname{Mix}(18)$ & $\operatorname{Mix}(7)$ \\
\hline P. pat $\times$ greg & $\operatorname{Mix}(14)$ & Mix (20) & & & & \\
\hline P. pat $\times t e c \mathrm{H}$ & & $1(19)$ & $19(503)$ & $33(1$ 108) & 27 (840) & $21(716)$ \\
\hline P. pat $\times t e c L$ & $26(461)$ & $22(508)$ & & 87 (2 813) & 76 (2 109) & 78 (2 515) \\
\hline $\begin{array}{l}\text { P. taeda } \\
\text { P. tec LE }\end{array}$ & & & Mix (69) & Mix (29) & Mix (31) & Mix (34) \\
\hline
\end{tabular}
error term.

Table 2: Outline of taxa used for each site showing the number of families and total number of trees (indicated in parentheses) used in the analyses. Mix $=$ seedlot from two or more families from the same species

a The taxon full names are: $P$. ell $\times$ car $=P$. elliottii $\times P$. caribaea var. hondurensis; $P$. pat $\times$ greg $=P$. patula $\times P$. greggii; $P$. pat $\times$ tech $=P$. patula $\times$

$P$. tecunumanii High elevation $(\mathrm{HE}) ; P$. pat $\times$ tecL $=P$. patula $\times P$. tecunumanii Low elevation $(\mathrm{LE}) ; P$. tecLE $=P$. tecunumanii Low elevation 


\section{Results}

\section{Survival}

The five-year average survival for the six sites was more than $70 \%$ except for Spitskop1, which was $44 \%$. The survival rates for the individual entries on this latter site were all below $60 \%$, with $\mathrm{F}_{1} P$. patula being the worst (Figure 1). Both $P$. patula hybrids on this site had poorer survival than the other five sites. At Tweefontein, the survival for $P$. patula was $20 \%$, which was worse than any of the other sites.

During the first year following trial establishment, dying $P$. patula plants from the Tweefontein site were sent to the Forestry and Agriculture Biotechnology Institute (FABI) at the University of Pretoria to be screened for the presence of $F$. circinatum. The fungus was found to be present on most samples, suggesting the poor survival of this entry was most likely due to infection by $F$. circinatum. The $P$. patula hybrids showed better survival than $P$. patula in the presence of $F$. circinatum in all cases for trials planted after 2007.

\section{Growth}

Site index is a tool used to measure a forest's potential productivity for a specific species at a defined base age (Kodani et al. 2010). Tree samples that have an undamaged stem, uniform annual height and dominant crown are used to determine the site index. Total tree height is measured and the growth rings are counted at $1.3 \mathrm{~m}$ to determine breast height age. The tree height and $\mathrm{DBH}$ is used to predict timber productivity, wood volume and growth rate on a specific site.

The estimated site indices for the trial sites range from 23 to $30 \mathrm{~m}$ at 20 years of age, calculated for either $P$. patula or $P$. elliottii as model species to calibrate each site. The estimated site indices were from the compartment registers developed by the Planning department at Komatiland Forests. Individual tree height, which was collected during assessment, was used to identify the tallest and shortest trees (data not presented). Actual measurements in trials had the tallest $P$. patula tree at $13.4 \mathrm{~m}$ with an average height of $7.8 \mathrm{~m}$ and the $P$. patula $\times P$. tecunumanii LE tallest tree was $15.6 \mathrm{~m}$ with an average of $9.2 \mathrm{~m}$. On average $P$. patula $\times P$. tecunumanii LE was between $9.5 \%$ and $51 \%$ taller than the improved $P$. patula $\left(\mathrm{F}_{2}\right)$, and between $6 \%$ and $15 \%$ taller than $P$. patula $\times P$. tecunumanii $\mathrm{HE}$. Based on these assessments, the $P$. patula $\times P$. tecunumanii LE hybrid, being faster growing than $P$. patula, $P$. elliottii and $P$. taeda, is predicted to be over $35 \mathrm{~m}$ at age 20 years. This assumption is based on the fact that at five years the hybrid is on average $30 \%$ taller than $P$. patula.

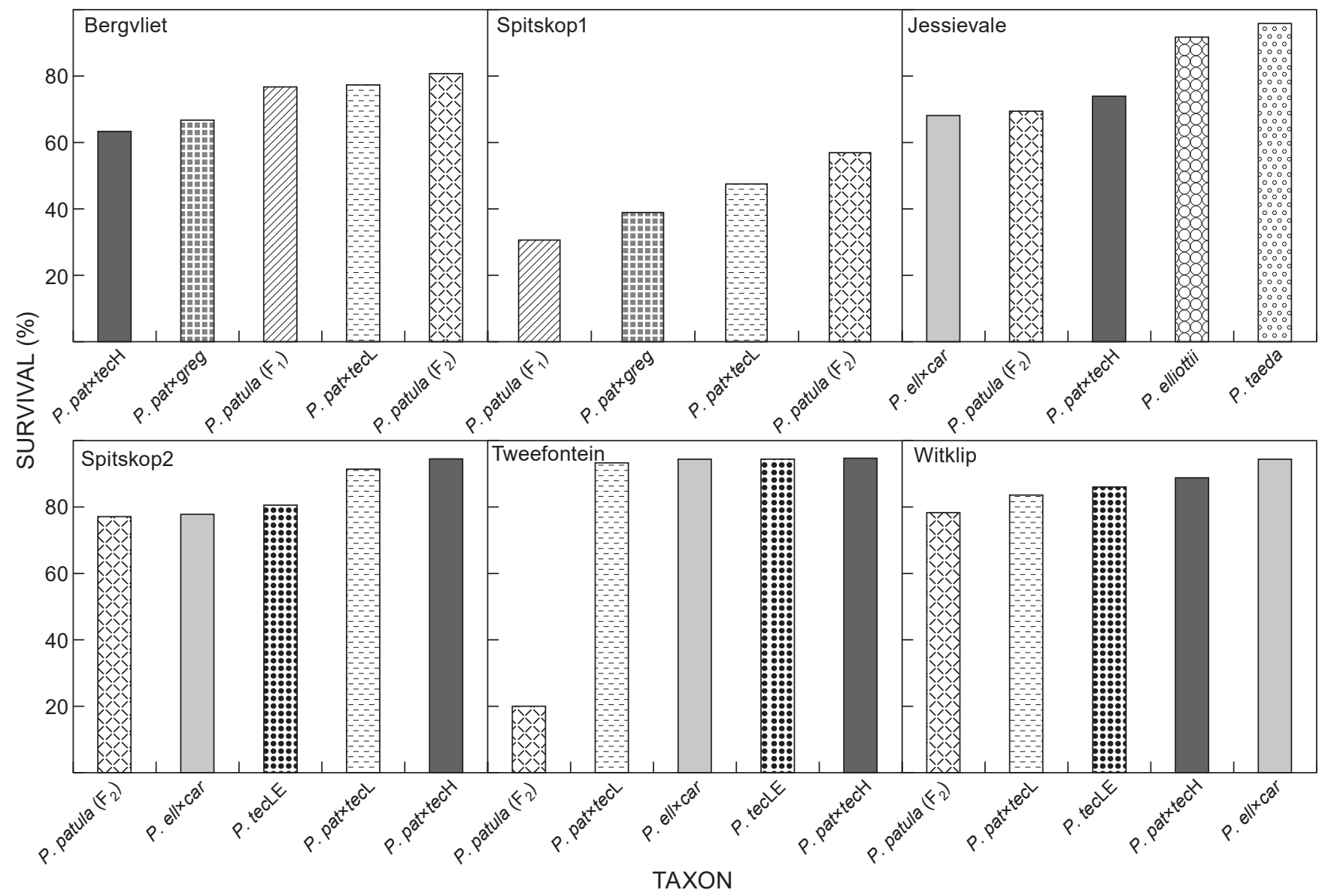

Figure 1: Five-year survival of the trials across six sites. $P$. ell $\times$ car $=P$. elliottii $\times P$. caribaea var. hondurensis; $P$. pat $\times$ greg $=P$. patula $\times$ $P$. greggii; $P$. pat $\times$ tec $\mathrm{H}=P$. patula $\times P$. tecunumanii High elevation $(\mathrm{HE}) ; P$. pat $\times$ tecL $=P$. patula $\times P$. tecunumanii Low elevation $(\mathrm{LE}) ; P$. tecLE $=P$. tecunumanii $\mathrm{LE}$ 


\section{Volume estimation}

In forestry, productivity is measured by volume of wood produced. There were significant differences $(P<0.0001)$ between the species for volume at each site, when analysed individually (Table 3 ). The interaction between site and species was highly significant. Site and species effect was highly significant (Table 3 ). However, on Bergvliet volume of $P$. patula $\times P$. greggii was greater than $P$. patula $\times P$. tecunumanii LE. Pinus patula $\times P$. tecunumanii $\mathrm{LE}$ was significantly larger than all other entries (Figure 2). Volumes of $P$. elliottii $\times P$. caribaea and $P$. patula $\times P$. tecunumanii $\mathrm{HE}$ at Tweefontein were not statistically different (Figure 2). At Tweefontein, Witklip and Berglviet, $P$. patula $\times$ $P$. tecunumanii LE was significantly different to $P$. patula $\left(F_{2}\right)$. However, no difference was observed between the two entries at Spitskop1 and 2 (Figure 2). There were also no differences observed for $P$. patula $\left(F_{2}\right)$ and $P$. patula $\times P$. tecunumanii HE at Spitskop2 and Jessievale, but $P$. patula $\times P$. tecunumanii $\mathrm{HE}$ was significantly different to $P$. patula at Tweefontein and Bergvliet.

The mean volumes at Jessievale and Spitskop1 were not significantly different (Table 4). The other four sites were significantly different from each other with Witklip having the highest volume $\left(0.0774 \mathrm{~m}^{3}\right)$. The volume for $P$. patula at Witklip was $55 \%$ more than that at both Spitskop2 and Tweefontein. Volume of $P$. patula $\times P$. tecunumanii LE was significantly higher than all other entries on all sites except for $P$. elliotti $\times P$. caribaea at Spitskop2 with a $2 \%$ difference in volume, and at Tweefontein and Witklip the difference was $16 \%$ to $24 \%$ (Figure 2 ).

Table 3: Across site analysis of variance for volume at five years of age

\begin{tabular}{lrccrc}
\hline Source & \multicolumn{1}{c}{ df } & Sum of squares & Mean square & $F$-value & $\operatorname{Pr}>F$ \\
\hline Replicate & 29 & 0.1458 & 0.0050 & 6.82 & $<0.0001$ \\
Site & 5 & 0.1537 & 0.0307 & 41.72 & $<0.0001$ \\
Taxon & 9 & 0.1249 & 0.0139 & 18.84 & $<0.0001$ \\
Site*Taxon & 14 & 0.0665 & 0.0048 & 6.44 & $<0.0001$ \\
Error & 12318 & 9.0811 & 0.0007 & & \\
Corrected total & 12375 & 13.2405 & & & \\
\hline
\end{tabular}
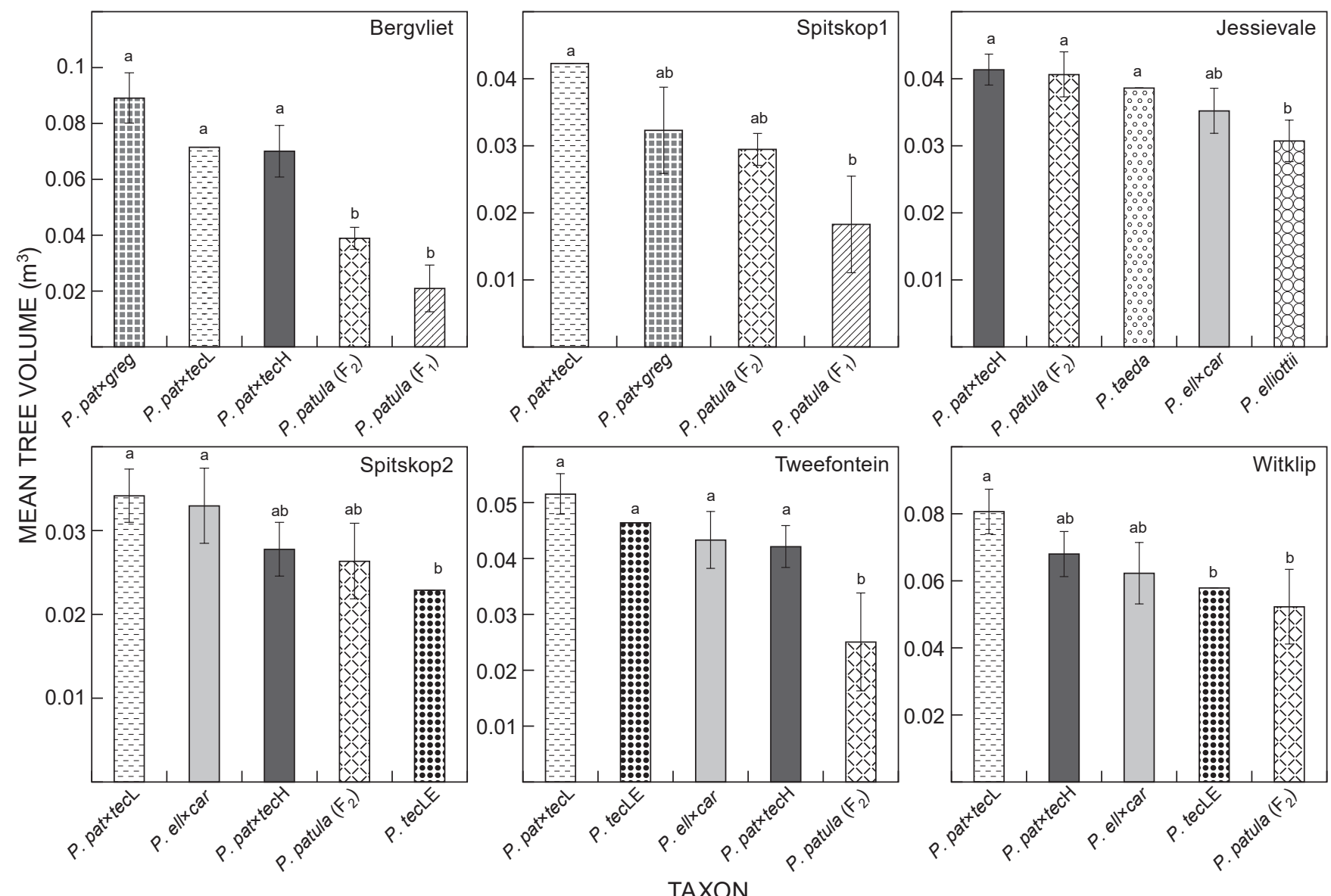

Figure 2: Mean tree volume for the various taxa at the six sites at five years of age. Error bars represent the SE. Different letters above bars indicate a significant difference at the $5 \%$ significance level 
At Jessievale $P$. patula $\times P$. tecunumanii $\mathrm{HE}$ was not significantly different from $P$. patula (Figure 2). At Tweefontein, $P$. patula $\times P$. tecunumanii LE had $65.7 \%$ more volume than $P$. patula $\left(\mathrm{F}_{2}\right)$, and at Bergviet it had $60 \%$ higher volume than $P$. patula $\left(F_{2}\right)$ and $110 \%$ greater volume than $P$. patula $\left(\mathrm{F}_{1}\right)$. At Spitskop1 $P$. patula $\times P$. tecunumanii LE had $38 \%$ more volume than $P$. patula and $39 \%$ greater volume than $P$. patula at Witklip. The volumes of $P$. patula $\left(\mathrm{F}_{2}\right)$ and $P$. patula $\times P$. tecunumanii $\mathrm{HE}$ at Jessievale were not significantly different from each other (Figure 2).

\section{Wood quality: modulus of elasticity}

Data for $\mathrm{MOE}_{\mathrm{dym}}$ are presented for the three sites at

Table 4: Site means for volume at five years. Means followed by a different superscript letter differ at $5 \%$ significance level

\begin{tabular}{lc}
\hline Site & Mean volume $\left(\mathrm{m}^{3}\right)$ \\
\hline Witklip & $0.0774^{\mathrm{a}}$ \\
Bergvliet & $0.0648^{\mathrm{b}}$ \\
Tweefontein & $0.0500^{\mathrm{c}}$ \\
Jessievale & $0.0397^{\mathrm{d}}$ \\
Spitskop1 & $0.0390^{\mathrm{d}}$ \\
Spitskop2 & $0.0337^{\mathrm{e}}$ \\
\hline
\end{tabular}

Tweefontein, Witklip and Spitskop2. The other three sites were not measured for $\mathrm{MOE}_{\text {dym }}$ during assessments. Significant differences $(p<0.0001)$ were observed between the taxa when analysed individually at each site (Figure 3). There were also significant site differences and a significant site $\times$ taxa interaction (Table 5). The mean $\mathrm{MOE}_{\text {dym }}$ of $P$. tecunumanii LE was higher than that of $P$. patula at all three sites, and $P$. patula $\times P$. tecunumanii LE produced larger $\mathrm{MOE}_{\mathrm{dym}}$ values than $P$. patula $\times P$. tecunumanii $\mathrm{HE}$.

At Spitskop2, $\mathrm{MOE}_{\mathrm{dym}}$ of $P$. tecunumanii LE was significantly different from all other entries. However, $P$. patula $\left(\mathrm{F}_{2}\right)$ and the $P$. patula $\times P$. tecunumanii hybrids were not significantly different from each other. It was also observed at Tweefontein and Witklip that $P$. patula $\left(\mathrm{F}_{2}\right)$ and $P$. patula $\times P$. tecunumanii were not significantly different from each other. On the latter sites, $P$. patula $\times P$. tecunumanii had better wood properties than $P$. patula $\left(\mathrm{F}_{2}\right)$.

A site effect for $\mathrm{MOE}_{\text {dym }}$ was observed (Figure 3 ). The Witklip site is at lower elevation (1 071 masl) than the other two sites. Furthermore, it is located close to the Witklip dam, which may have an impact on the microenvironmental conditions in the area. The differences in performance may be attributed to soil properties and elevation, as has been reported elsewhere (Dvorak et al. 2000a, 2000b).

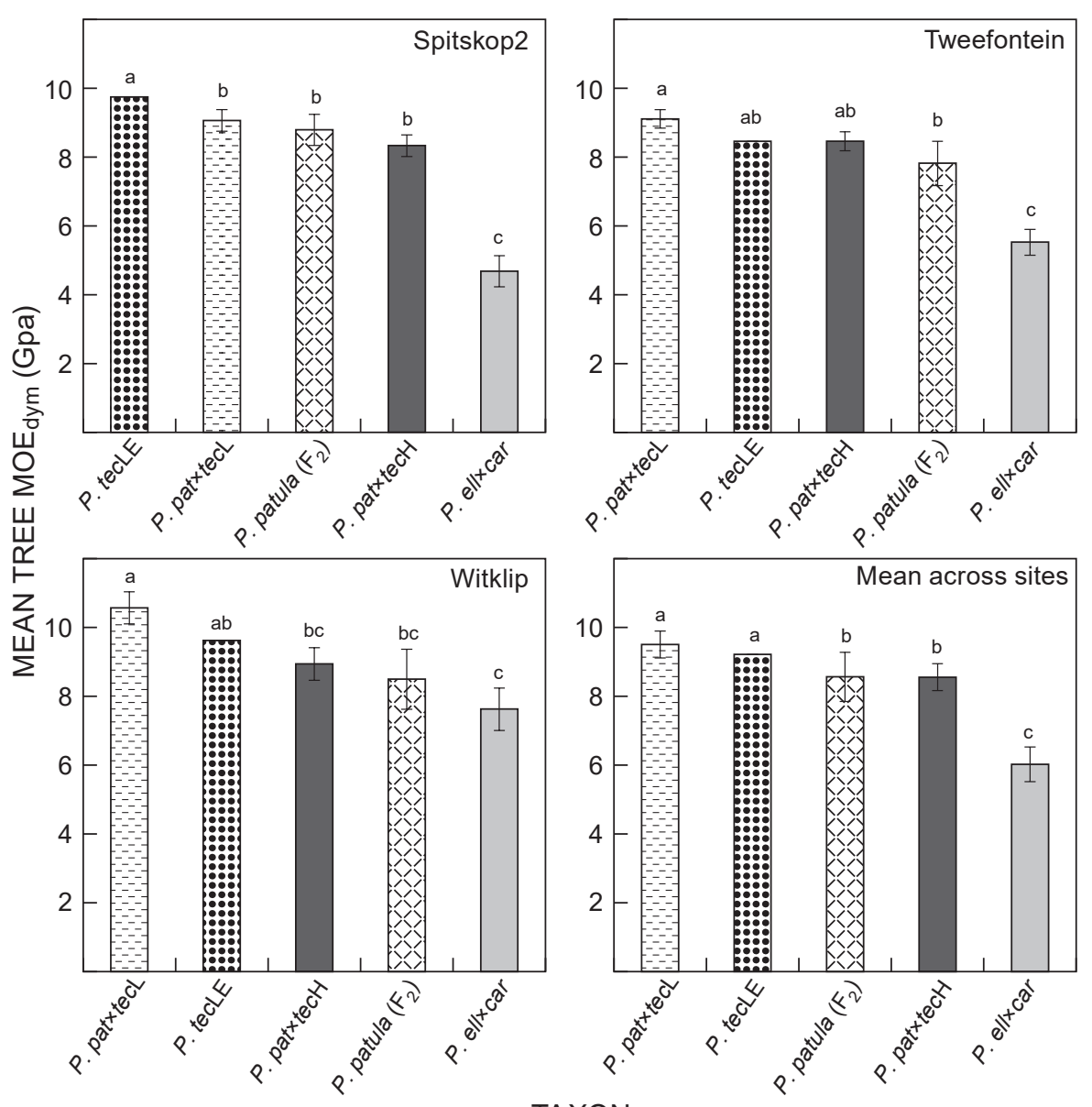

TAXON

Figure 3: Mean dynamic modulus of elasticity $\left(\mathrm{MOE}_{\mathrm{dym}}\right)$ at $5 \%$ significance level for the various taxa at the three sites, and interaction of the species across the three sites at five years. Error bars represent the SE. Different letters above bars indicate a significant difference at the $5 \%$ significance level 


\section{Discussion}

Hybridisation provides new genetic combinations that potentially have better characteristics than the parent species (Garrett and Trew 1986; Dungey 2001). As a result of hybridisation, new genetic combinations may show improved growth, wood-quality traits and adaptability in different environmental conditions, which adds value to breeding programmes and subsequent commercial deployment. Results for $P$. patula $\times P$. tecunumanii and $P$. patula $\times P$. oocarpa hybrids demonstrates that hybridisation can result in improved tolerance to pathogens such as F. circinatum (Dvorak et al. 2000a; Kanzler et al. 2012), over that of $P$. patula. Dying $P$. patula seedlings were confirmed to be infected by $F$. circinatum, which also affected in-field survival. The results in this present study support earlier work reported by Kanzler et al. (2012) conducted in Swaziland (Usutu) and the KwaZulu-Natal Midlands.

Generally, $P$. patula $\times P$. tecunumanii LE performed well for volume across all sites where it was tested. These studies have demonstrated that the $P$. patula $\times$ $P$. tecunumanii hybrid can produce greater volume than $P$. patula over a range of environmental conditions. Similar results were reported by Kanzler et al. (2012). The $P$. patula $\times P$. tecunumanii LE hybrid had between $26 \%$ and $66 \%$ more volume than on the Mpumalanga escarpment. There was no significant difference between $P$. patula and $P$. patula $\times P$. tecunumanii $\mathrm{HE}$ at Jessievale. It was interesting to note that the $P$. patula $\times P$. greggii hybrid, which was included on two lower-elevation sites, had $24 \%$ more volume than $P$. patula $\times P$. tecunumanii at Bergvliet and $34 \%$ less volume at Spitskop1. This hybrid might do well on colder/harsher sites such as Jessievale.

The site at Bergvliet is approximately $300 \mathrm{~m}$ lower in altitude and is drier than Spitskop1 (Table 1). Spitskop2 is about $200 \mathrm{~m}$ higher than Tweefontein. The sites receive similar amounts of precipitation but $P$. patula at Tweefontein had $19 \%$ more volume than Spitskop2. The trend suggests that altitude has an impact on the volume and growth rate. The trials were planted $30 \mathrm{~d}$ apart and the survival was $50 \%$ better at Sptiskop2. Similar observations were made on $P$. patula $\times P$. tecunumanii where, across an altitudinal range, volume decreased with increasing altitude (Figure 4). The gradient of the $P$. patula $\times P$. tecunumanii LE is larger than that of $P$. patula and the volume of both species will be the same at a certain altitude; however, as altitude increases, $P$. patula $\times P$. tecunumanii LE will be outperformed by $P$. patula. At 1723 masl (Jessievale), the study found no difference between the volumes of $P$. patula and $P$. patula $\times P$. tecunumanii $\mathrm{HE}$. There was an inverse relationship between volume and altitude. This was also noted by Kanzler

Table 5: Dynamic modulus of elasticity analysis of variance for site and species across the three test sites at five years

\begin{tabular}{lrrrrc}
\hline Source & \multicolumn{1}{c}{ df } & Sum of squares & Mean square & $F$-value & $\operatorname{Pr}>F$ \\
\hline Site & 2 & 150.3448 & 75.1724 & 22.14 & $<0.0001$ \\
Taxon & 4 & 2789.6659 & 697.4164 & 205.40 & $<0.0001$ \\
Site*Taxon & 8 & 365.3565 & 45.6695 & 13.45 & $<0.0001$ \\
Error & 9900 & 33613.7689 & 3.3953 & & \\
Corrected total & 9914 & 39701.7523 & & & \\
\hline
\end{tabular}

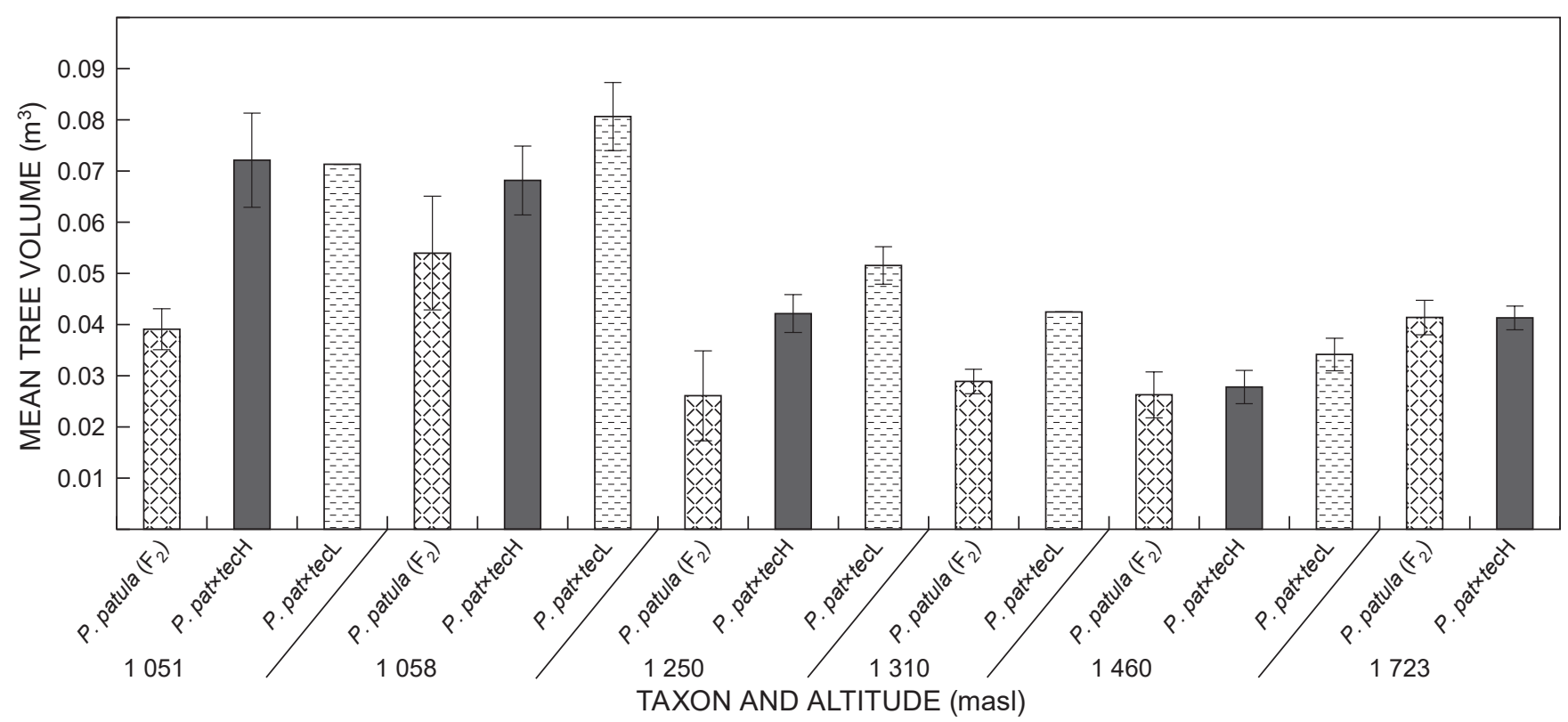

Figure 4: Pinus patula $\times P$. tecunumanii and $P$. patula volume across an altitudinal range. The location of the altitudes are shown in Table 1 . Error bars represent the SE 
et al (2014) when comparing $P$. patula $\times P$. tecunumanii LE and $P$. patula $\times P$. tecunumanii HE across elevations.

The above discussion suggests that for maximum growth and production, there is a niche area in which the hybrid performs best. At this stage, it would appear to be temperature-driven, although an improved understanding of other environmental conditions, such as geology, climate, soil and water, will improve our understanding of these relationships. Plant growth is greatest on moist sites, whereas growth is reduced on colder and drier sites.

We might expect the taxa to perform best to worst from a warm to a cold environment, as the present study has demonstrated and as the trend shows in Figure 4. On the warmer sites $P$. tecunumanii LE and $P$. patula $\times$ $P$. tecunumanii LE might be expected to adapt very well. Pinus tecunumanii $\mathrm{HE}$ and $P$. patula $\times P$. tecunumanii $\mathrm{HE}$ might be expected to adapt in the mid-range between warm and cold conditions, with $P$. patula adapting well on the colder sites.

The SABS 0163-2 (2001) has established a correlation between the MOE and minimum densities for each grading according to the SANS 10163-1 (2003) standard. The strength properties of $P$. patula $\times P$. tecunumanii LE wood was comparable to or even better than that of $P$. patula and met the S5 requirements on two sites, namely Spitskop2 and Witklip. This trait is most likely to have been contributed by the $P$. tecunumanii LE parent (Figure 3), as supported in previous studies (Garrett and Trew 1986; Dvorak et al. 2000a, 2000b; Dungey 2001). If the $P$. elliottii $\times P$. caribaea hybrid is removed from Figure 3 , there would be no significant differences between the $P$. patula hybrids, $P$. patula and $P$. tecunumanii. Pinus elliotti $\times P$. caribaea did not meet the $\mathrm{S} 5$ grade minimum specifications at this young age.

\section{Conclusions}

The $P$. patula $\times P$. tecunumanii LE hybrids were found to have faster growth, better $\mathrm{MOE}_{\mathrm{dym}}$ and good survival across a range of sites in the Mpumalanga forestry region. This confirms the findings of Dvorak et al. (2000a) on the advantages of $P$. tecunumanii hybrids. The general $\mathrm{MOE}_{\mathrm{dym}}$ shows that sites at a lower elevation had higher $\mathrm{MOE}_{\mathrm{dym}}$ than those at higher altitude, which concurs with other reports that there is an inverse relationship between some wood-quality properties and elevation (Schutz et al. 1991; McCallum et al. 2007). Pinus patula $\times P$. tecunumanii LE met the minimum requirement for $\mathrm{MOE}_{\text {dym }}$ as specified by the SANS standard. The $P$. patula $\times P$. tecunumanii hybrids were comparable to $P$. patula, and in the case of $P$. patula $\times P$. tecunumanii LE, the evidence suggests that it is generally superior in volume and it is probably due to the contribution of $P$. tecunumanii LE as a parent.

This study has shown that the volume production for both species is comparable at five years of age, but the $P$. patula $\times P$. tecunumanii LE hybrid can provide a more productive alternative to $P$. patula in the escarpment region of Mpumalanga. In the Highveld region, $P$. patula $\times P$. tecunumanii $\mathrm{HE}$ and $P$. patula were not significantly different in volume. This could mean that $P$. patula is still the best option on very cold sites. This study has shown that the volume production for both species is comparable at five years of age. It is clear that the productivity of $P$. patula $\times P$. tecunumanii LE decreases with increasing elevation and there is a cut-off altitude where it should be replaced by $P$. patula $\times P$. tecunumanii HE hybrid. More studies are needed to determine the exact niche and altitude boundaries for each of the taxa.

More trials need to be established in the Highveld to find suitable alternative taxa. In-depth site and environmental studies need to be conducted where such hybrids are planted to understand their requirements and behaviour in those environments. With more studies conducted, environmental sensitivity of the pine hybrids may be understood, which in turn will help in successfully deploying them commercially.

Acknowledgements - We acknowledge Komatiland Forests Research staff for their contribution in these studies from planting to assessment of the trials.

\section{References}

Apiolaza LA, Walker JCF, Nair, H, Butterfield B. 2008. Very early screening of wood quality for radiata pine: pushing the envelope. In: Proceedings of the 51st Annual Convention of the Society of Wood Science and Technology, 10-12 November 2008, Conception, Chile. Paper WQ-1: 7 pages.

Dungey HS. 2001. Pine hybrids - a review of their use performance and genetics. Forest Ecology and Management 148: 243-258.

Dvorak WS, Gutierrez EA, Hodge GR, Romero JL, Stock J, Rivas O. 2000a. Pinus caribaea var. hondurensis. In: Conservation and testing of tropical and subtropical forest tree species by the CAMCORE Cooperative. Botha Hill, South Africa: Grow Graphics. pp 12-33.

Dvorak WS, Hodge GR, Gutierrez EA, Osorio LF, Malan F, Stanger TK 2000b. Pinus tecunumanii. In: Conservation and testing of tropical and subtropical forest tree species by the CAMCORE Cooperative. Botha Hill, South Africa: Grow Graphics. pp 189-209.

Dvorak WS, Hodge GR, Kietzka JE, Malan F, Osorio LF, Stanger TK. 2000c. Pinus patula. In: Conservation and testing of tropical and subtropical forest tree species by the CAMCORE Cooperative. Botha Hill, South Africa: Grow Graphics. pp 149-173.

Garrett PW, Trew IF. 1986. Resistance of pitch $\times$ loblolly pine hybrids to fusiform rust (Cronartium quercuum f. sp. fusiforme). Plant Disease 70: 564-565.

Hodge GR, Dvorak WS. 1999. Genetic parameters and provenance variation of Pinus tecunumanii in 78 international trials. Forest Genetics 6: 157-180.

Hodge GR, Dvorak WS. 2000. Differential response of Central American and Mexican pine species and Pinus radiata to infection by pitch canker fungus. New Forests 19: 241-258.

Hodge GR, Dvorak WS. 2007. Variation in pitch canker resistance among provenances of Pinus patula and Pinus tecunumanii from Mexico and Central America. New Forests 33: 193-206.

Johnson GR, Gartner BL. 2006. Genetic variation in basic density and modulus of elasticity of coastal Douglas-fir. Tree Genetics and Genomes 3: 25-33.

Kanzler A, Nel A, Ford C. 2014. Development and commercialisation of the Pinus patula $\times P$. tecunumanii hybrid in response to the threat of Fusarium circinatum. New Forests 45: 417-437.

Kanzler A, Payn K, Nel A. 2012. Performance of two Pinus patula hybrids in southern Africa. Southern Forests 74: 19-25.

Ladrach WE, Mazuera H. 1978. Growth and development of the Chupilauta Arboretum at 7 years, and the Mexican pines in San Jose at 6.3 years. Smurfit Cartón de Colombia Research Report 34. Cali: Smurfit Cartón de Colombia. 
Leibing C, Signer J, van Zonneveld M, Jarvis A, Dvorak W. 2013. Selection of provenances to adapt tropical pine forestry to climate change on the basis of climate analogs. Forests 4 : 155-178.

Lindström H, Reale M, Grekin M. 2009. Using non-destructive testing to assess modulus of elasticity of Pinus sylvestris trees. Scandinavian Journal of Forest Research 24: 247-257.

Lowell EC, Todoroki CL, Dykstra DP, Briggs DG. 2014. Linking acoustic velocity of standing Douglas-fir trees to veneer stiffness: a tree-log-product study across thinning treatments. New Zealand Journal of Forestry Science 44: 1, 16 pages.

Malan FS. 2010. Corewood in South African pine: necessity and opportunities for improvement. Southern Forests 72: 99-105.

McCallum DJ, Mason EG, Whitey B. 2007. Influence of exposure and elevation on radiata pine branch size, log velocity, sweep, taper and value. New Zealand Journal of Forestry 52(3): 10-16.

Mitchell RG, Steenkamp ET, Coutinho TA, Wingfield MJ. 2011. The pitch canker fungus, Fusarium circinatum: implications for South African Forestry. Southern Forests 73: 1-13.

Mitchell RG, Wingfield MJ, Hodge GR, Steenkamp ET, Coutinho TA. 2012. The tolerance of Pinus patula $\times$ Pinus tecunumanii, and other pine hybrids, to Fusarium circinatum in greenhouse trials. New Forests 44: 443-456.

Nilsson O. 2014. Growth and modulus of elasticity of selected pine species and hybrids three years after planting in South Africa. Master Thesis no. 222. Swedish University of agricultural Sciences, Alnarp, Sweden.
Roux J, Eisenberg B, Kanzler A, Nel A, Coetzee V, Kietzka E, Wingfield MJ. 2007. Testing of selected South African Pinus hybrids and families for tolerance to the pitch canker pathogen, Fusarium circinatum. New Forests 33: 109-123.

SABS 0163-2. 2001. The structural use of timber. Part 2: Allowable stress design. Edition 1.1. Pretoria: South African Bureau of Standards.

SABS 10163-1. 2003. The structural use of timber. Part 1: Limit-state design. Edition 2.3. Pretoria: South African Bureau of Standards.

SANS 1783-2. 2012. Sawn softwood timber. Part 2: Stress-graded structural timber and timber for frame wall construction. Edition 1.8. Pretoria: South African Bureau of Standards.

Schutz CJ, Christie SI, Herman B. 1991. Site relationships for some wood properties of pine species in plantation forests of southern Africa. South African Journal of Forestry 156: 1-6.

Viljoen A, Wingfield MJ, Kemp GHJ, Marasas WFO. 1995. Susceptibility of pines in South Africa to the pitch canker fungus Fusarium subglutinans f. sp. pini. Plant Pathology 44: 877-882.

Wang X, Carter P, Ross R, Brashaw BK. 2007. Acoustic assessment of wood quality of raw forest materials: a path to increased profitability. Forest Products Journal 57(5): 6-14.

Wielinga B, Raymond CA, James R, Matherson AC. 2009. Effect of green density values on Pinus radiata stiffness estimation using a stress-wave technique. New Zealand Journal of Forestry Science 39: 71-79. 